THURSDAY, APRIL 9, 1903.

\section{THE CORRESPONDENCE OF CHARLES} DARWIN.

More Letters of Charles Darwin. A Record of his Work in a Series of hitherto Unpublished Letters. Edited by Francis Darwin, Fellow of Christ's College, and A. L. Seward, Fellow of Emmanuel College, Cambridge. In two volumes, illustrated. vol. i., pp. xxiv +494 ; vol. ii., pp. viii +508 . (London: J. Murray, Ig03.) Price 32s. net.

$W^{E}$ close most biographies with the exclamation " too long and far too many letters," but the three volumes of the "Life and Letters of Charles Darwin," published in 1887 , left their readers, like young Oliver Twist, "asking for more." At that time considerations of space and other reasons prevented the editors from publishing numerous tetters in their possession, and since then many of great interest have been received. From this unused material they have compiled, with only a few slight repetitions, "an almost complete record of Darwin's work," which will be welcomed, we are sure, not only by students of science, but also by all interested in the history of the Earth and Man. It is now nearly forty-four years since the "Origin of Species" was first published. The book was received with objurgation by the many, with praise by the few, yet in about half that time it had forced its way to a front place among the classics of scientific literature, and though opinions still differ about the prime factor in producing a species, a place is assured to Charles Darwin among naturalists similar to that of Isaac Newton among physical mathematicians. The former, indeed, has effected, outside his own field, an even more rapid and extensive transformation of thought. The idea of evolution has acted like a solvent in subjects to which it might have been supposed alien, for it has even won recognition from theology, by the partisans of which it was at first so vociferously and ignorantly assailed. It has, in short, succeeded in revealing the "How" of the natural order, though making no pretence of fathoming the mystery of the "Why."

The "Life and Letters" contained an autobiographical sketch written in Darwin's later years for the information of his children. When the family removed from the old home at Down, they discovered a fragment of another-dated so long ago as $188_{3} 8$-which is included in the present work. This has a special value as containing fuller and clearer reminiscences of his childhood--information which is always welcome to the students of human nature, for the child in so many respects is the father of the man. From his earliest days Darwin was a collector of curiosities-sceking for minerals and stones before he was nine years oldand was always anxious to understand their structures and significance. He was not, however, quite a pattern good boy, for he confesses to flying into passions and often telling fibs These, however, were not to get him out of scrapes, but simply results of indulging a too vivid imagination, with the desire to astonish the hearers. The tenor of his letters and the devotion of his family circle prove beyond question how effectively he overcame the former fault, and his writings would almost lead us to think the latter incredible, for they show conscientious accuracy to have been one of his most marked characteristics. But it proved him to possess the imaginative faculty, without which perhaps no great generalisation has ever been made. Pegasus, indeed, must be ridden with a curb, but that steed alone can carry its rider across the bounds of space and time.

The present volumes pass briefly over school days at Shrewsbury, the short residence at Edinburgh, and the undergraduate life at Cambridge, where a friendship with Prof. Henslow proved the turning point of his career. Some half-dozen letters, written during his voyage on the Beagle-every one well worth preservation-are now printed for the first time, and two or three relating to his marriage and settling at Down. One, addressed to his fiancée, shows what the wives of scientific men have often to endure, for he confesses that Charles Lyell and he had been talking " unsophisticated geology" for half an hour, with " poor Mrs. Lyell sitting by a monument of patience," adding that he wants practice in ill-treating the female sex, for he did not observe Lyell had any compunction; "I hope to harden my conscience in time; few husbands seem to find it difficult to do this." But what he owed to this marriage we learn by an extract from his autobiography, which, now that Mrs. Darwin has passed away, is very rightly printed in the present work, for it shows what true and deep feeling lay beneath that calm exterior.

The period between his settling at Down and writing the "Origin of Species" is covered by fifty-eight letters, addressed chiefly to Huxley and Hooker, his most intimate friends. They form a very interesting addition to those already published in the second volume of the "Life and Letters," and throw further light upon the incubation of the idea which was to bring order out of a scientific chaos. Its publication was accelerated, as is well known, by the receipt of a nuanuscript from Dr. A. R. Wallace, proving that the conception which Darwin had been laboriously working out for some years had dawned upon the former during his researches in the Malay Archipelagro. No circumstances could have offered a more favourable opportunity for a wrangle about priority; they proved the nobility of both men's natures by cementing their friendship, and a correspondence discussing topics arising from the "Origin of Species" is not the least interesting part of the present work. With the appearance of the "Origin," the letters become more varied and the writers more numerous; points had to be defended or developed, and new facts sought in corroboration. To all thoughtful objectors Darwin replied with courtesy and candour; of ignorant vituperation he took no note, except sometimes to lament, if it were the illconsidered utterance of a fellow-student in science. Knowing that he had built upon the solid rock of fact, he went about his work with unruffled calmness, little heeding the storm which might rage outside.

The publication of the "Origin" seemed to act as a stimulant to greater literary activity, for it was

$$
\text { NO. } 1745 \text {. VOL. 67] }
$$


followed in due course by the "Fertilisation of Orchids," the "Movements of Climbing Plants," "Variation under Domestication," the "Descent of Man," "Insectivorous Plants," the "Expression of the Emotions," "Cross and Self Fertilisation in the Vegetable Kingdom," the "Different Forms of Flowers," the "Power of Movement in Plants," and the "Formation of Vegetable Mould through the Action of Worms," besides new editions of some of them and of the "Origin," with sundry miscellaneous papers. This period is dealt with in the second volume of the present work, and the editors have grouped the letters (which in some cases go back to much earlier dates) under three principal heads: Man, Geology and Botany, with a short concluding chapter containing some on the Vivisection Controversv and miscellaneous subjects. In that controversy--needless to say-Darwin showed no favour to the noisy fanatics who set more store by a dog than by a man, though, as he writes to Lord Playfair, he strongly objected to " useless vivisection," namely, that undertaken for lecture-room experiments and without employing anæsthetics. That opinion had been also expressed fully in the "Life and Letters," but in view of "antivivisection tactics" the editors have been prudent in not omitting some reference to it in the present work.

The letters on geological subjects are very interesting, for with this science, though diverted from it in later life by pressure of other work, he never lost touch. As the volume of "Geological Observations" is still constantly in the student's hands, we need not enlarge upon its value, but the present work preserves for us numerous letters to Lyell and others on earthmovements, ice action, and the connection of cleavage with foliation, subjects in which Darwin's views may still be read with profit. In the first group he maintains that, as a rule, movements of elevation and depression generally affect large areas of the earth's crust, an opinion which has of late been gaining ground. Those on ice form a commentary on the views of its action, which were in process of change during his lifetime. Some of them relate to the noted Parallel Roads of Glenroy, on which he once wrote. He had then regarded them as old sea beaches, but abandoned this opinion in favour of the lake-side and ice-dam hypothesis. It would have been interesting to have seen how he would have dealt with the serious difficulty of the absence of glaciers from Glenroy, though an enormous dam is called into existence in neighbouring valleys. Perhaps this would have made him doubtful whether second thoughts are always best. As to cleavage and foliation, Darwin maintains that they have, as a rule, the same origin, instead of the latter being a result of stratification. That view is now accepted in a large number of cases, and his remarks on the connection of foliation with fuxion in igneous rocks show how acutely he observed and reasoned.

We are tempted to linger over these and the important group of letters on botanical subjects, but must hasten to a conclusion. It only remains to thank the editors for the way in which they have executed their task, and for these interesting volumes. They are most valuable, not only as a contribution to the history of science, but also as placing in clearer light the man himself. They were written currente calamo, as he rested in his armchair during the earlier afternoon, by way of relaxation from his more serious labours, so such slips of the pen as are indicative of fatigue or weakened health were not uncommon, yet they are often admirably expressed, and always attractive in their simplicity. Full of suggestive remarks, many of which will not readily become obsolete, they bring into clear relief Darwin's marvellous steadfastness of purpose, unflagging industry and patient endurance of the burden of chronic ill-health. This alone would have rendered many a man fretful or despondent; the letters, no less than the testimony of his family, prove that Charles Darwin had learnt the hardest of all lessons, "to suffer without complaining." We find in them repeated evidence of his freedom from acrimony or resentment, of his sympathy with other workers, and of that grand combination of a genuine humility with an almost unconscious intellectual strength, which impressed itself so deeply on all younger men. The life and the letters of Darwin have an ethical as well as a scientific value, for he was one of those who wore " the white flower of a blameless life," and could have faced without shrinking " that fierce light which beats upon a throne." T. G. Bonney.

\section{CAN THESE BONES LIVE?}

Grundrisz der Mineralogie und Geologie, zum Gebrauch beim Unterricht an höheren Lehranstalten sowie zum Selbstunterricht. By Prof. Dr. Bernhard Schwalbe. Edited by Prof. Dr. H. Böttger, Pp. xviii + viii + 766. (Braunschweig: Vieweg und Sohn, I903.) Price 13.50 marks.

$T$ was in the forest-country south of Greifswald, 1 where the wind sweeps down the highway from the grey-green Baltic, and crashes the pine-stems one against another, and blots out the shafts of a cold sunlight in sudden sheets of rain-it was here that we took shelter in a little wayside inn, and meditated on the vast uniformity of the Pomeranian plain. And here our host was a quiet old gentleman, a Vorsteher of something that demanded the imperial regard, the headman of a hamlet of five houses, and of finer education than the average burgess of an English country town.

He found out where we came from, and read to us from the English Bible, commenting on its archaic style. He then turned to Shakespeare, and finally left us with a copy of Carlyle's "Frederick the Great." When asked where he acquired this learning, he replied, "In the gymnasium at Greifswald."

And the work the full title of which stands above is also a product of gymnasia. In the hands of an inspired teacher, pupils might even become fond of it; but we are lost in admiration, tempered with sorrow, for those who would enter on it with a view to "Selbstunterricht." Our host in the Pomeranian flatland was probably capable of such greatness. House after house, moreover, throughout Germany boasts a "Con-

No. I 745 , VOL. 67$]$ 